Plant Tissue Cult. \& Biotech. 31(2): 143-151, 2021 (December)

DOI: https://doi.org/10.3329/ptcb.v31i2.57342

(C)Bangladesh Assoc. for Plant Tissue Culture \& Biotechnology
ISSN 1817-3721, E-ISSN 1818-8745

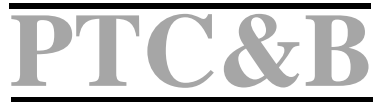

\title{
In vitro Regeneration of Picralima nitida (Stapf). T. Durand \& H. using Zygotic Embryo
}

\section{Kamdem, Nehemie Tchinda Donfagsiteli', Njoueretou Mfondi Mache, Carine Temegne Nono, Rodrigue Goimasse, Leila Zebaze Zambou', Justine Germo Nzweundji', Emmanuel Youmbi and Libert Brice Tonfack*}

Physiology and Plant Improvement Unit, Laboratory of Biotechnology and Environment, Department of Plant Biology, Faculty of Science, University of Yaounde I, P.O. Box 812, Yaounde, Cameroon

Keywords: 2,4-D, acclimatisation, Disinfection, Picralima nitida regeneration, Zygotic embryogenesis

\begin{abstract}
Disinfected mature seed embryos of Picralima nitida, were cultured in MS medium supplemented with different concentrations and combinations of 2,4-D, BAP and NAA to determine an efficient protocol for in vitro propagation. Nine culture media made of combination of different components were used in a factorial design with three replications. Results showed up to $80 \pm 4 \%$ disinfection rate with combination of triton $x-$ $100(0.2 \%)$ and sodium hypochlorite $(30 \%)$. Embryo germination was highest on control medium. Rooting was higher $(2 \pm 1$ roots per embryo) after 4 weeks on control medium and on BAP supplemented medium at $0.8 \mu \mathrm{M}$ while the longest root $(1.5 \pm 0.5 \mathrm{~cm})$ was observed on 2,4-D supplemented medium at $1.8 \mu \mathrm{M}$. Black soil was suitable for leaf formation $(4 \pm 2$ leaves) and shoot elongation $(2 \pm 1 \mathrm{~cm})$ after 8 weeks in acclimatisation. These results show efficient disinfection, regeneration and acclimatisation of Picralima nitida.
\end{abstract}

\section{Introduction}

Picralima nitida is a wild medicinal tree belonging to the Apocynaceae family. The use of this plant in traditional medicine is highly appreciated for the treatment of several diseases including typhoid, fever, anaemia, jaundice, dysmenorrhoea (Jiofack et al. 2009),

*Author for correspondence: <libert-brice.tonfack@facsciences-uy1.cm>. ${ }^{1}$ Medicinal Plants and Traditional Medicine Research Centre, Institute of Medical Research and Medicinal Plants Studies, P.O. Box 6163, Yaounde, Cameroon. 
malarial, psychosis, local pains (Okunji et al. 2005). The antimicrobial properties of $P$. nitida (Fakeye et al. 2004, Nkere and Iroegbu 2005) as well as the hypoglycaemic (InyaAgha et al. 2006; Nwakile and Okere 2011) and antidiarrheal (Kouitcheu et al. 2006) activities of its seed extracts have been documented, justifying believes that the plant could cure COVID-19 (Ogbole et al. 2018, Inkoto et al. 2020). Regarding its high socioeconomic value, the plant has been classified among the priority species for domestication in Cameroon (Jiofack et al. 2010). Moreover, the species is over-exploited by the populations and is currently rarer.

Indeed, the natural regeneration of $P$. nitida is difficult because the seeds are dormant and recalcitrant. It is known that most tropical forest species have seeds that are recalcitrant and therefore do not germinate easily even under the most favourable conditions (Chin et al. 1989). To cope with this difficulty, in vitro culture, especially embryo culture, could contribute to the regeneration of P. nitida. Embryos that cannot survive in vivo or are dormant for long periods can be rescued in vitro (Grosser and Gmitter 2011). This technique has been used for many species such as: Cocos nucifera (Ledo et al. 2001, Fuentes et al. 2005, Ledo et al. 2007), Desmoncus orthacanthos (Tzec-Simá et al. 2006), Elaeis guineensis (Thawaro and TeChato 2010, Tabi et al. 2016).

Few studies on micropropagation of $P$. nitida, leading to effective plantlet establisment have not been conclusive (Gbadamosi 2013). To date, our knowledge is very limited on in vitro regeneration of $P$. nitida through zygotic embryo culture and acclimatisation. The aims of this study was to establish a protocol describing favourable conditions for in vitro regeneration of $P$. nitida from seed embryo disinfection to seedling acclimatisation.

\section{Materials and Methods}

The plant material was seeds of Picralima nitida, used to extract the mature zygotic embryo (MZE) and collected from mature fruits harvested on 3-5 years old plants in Yaounde, Cameroon.

Mature zygotic embryos (MZEs) were delicately extracted from seeds and disinfected according to Gautheret (1959) modified method. In order to find the best balance between the effectiveness of the disinfection and germination, MZEs were first washed with tap water for $5 \mathrm{~min}$ and submitted to four different disinfection treatments (Table 1). The explants were placed in 30\% sodium hypochlorite $(\mathrm{NaClO})$ for $10 \mathrm{~min}(\mathrm{D} 1) ; 95^{\circ}$ ethanol for $30 \mathrm{~s}$ and D1 (D2); $0.2 \%$ of Triton X-100 for $8 \mathrm{~min}$, then D1 (D3); $0.2 \%$ of Triton $X-100$ for $8 \mathrm{~min}$, then in $40 \% \mathrm{NaClO}$ for $10 \mathrm{~min}$ (D4). After each of the four disinfection treatments, the MZEs were rinsed three times with sterile distilled water for 5 min each. The disinfection rate was determined as the percentage of non-pollution.

For the germination and rooting, the disinfected embryos were placed in MS medium with Heller's macro and sucrose at $175 \mathrm{mM}$. Pairwise combinations of Dimethylamine salt or 2,4-D (0, 0.36 and $1.8 \mu \mathrm{M})$, BAP $(0,0.8,1.3,2.2$ and $4.4 \mu \mathrm{M})$ and/or 
NAA $(0,1$ and $1.5 \mu \mathrm{M})$ was used (Table 1$)$. The control medium was not supplemented with hormones. The $\mathrm{pH}$ of the culture media was adjusted to 5.9 before autoclaving at $121^{\circ} \mathrm{C}$ for $20 \mathrm{~min}$ at the pressure of 1 bar. Germination, number of rooted embryos followed by root elongation and average number of roots per embryo were evaluated. The cultures were carried out at $25 \pm 2^{\circ} \mathrm{C}$, with 16 and $8 \mathrm{hrs}$ of light and darkness, respectively. For each experiment, 20 explants were used in three replications.

Table 1. Disinfection techniques and pairwise combinations of phytohormones used to supplement the different culture media.

\begin{tabular}{|c|c|c|c|c|c|c|c|}
\hline \multirow{2}{*}{$\begin{array}{l}\text { Disinfection } \\
\text { technique }\end{array}$} & \multicolumn{3}{|c|}{ Component, time } & \multirow{2}{*}{$\begin{array}{l}\text { Culture } \\
\text { medium }\end{array}$} & \multicolumn{3}{|c|}{ Phytohormone $(\mu \mathrm{M})$} \\
\hline & Ethanol & $\begin{array}{l}\text { Sodium } \\
\text { hypochlorite }\end{array}$ & $\begin{array}{l}\text { Triton X- } \\
100\end{array}$ & & NAA & BAP & $2,4-\mathrm{D}$ \\
\hline D1 & - & $30 \%, 10 \mathrm{~min}$ & - & $\mathrm{H} 1$ & 0.0 & 0.0 & 0.0 \\
\hline D2 & $95^{\circ}, 30 \mathrm{~s}$ & $30 \%, 10 \mathrm{~min}$ & - & $\mathrm{H} 2$ & 0.0 & 0.0 & 1.8 \\
\hline D3 & - & $30 \%, 10 \mathrm{~min}$ & $0.2 \%, 8 \mathrm{~min}$ & H3 & 0.0 & 0.8 & 0.0 \\
\hline \multirow[t]{6}{*}{ D4 } & - & $40 \%, 10 \mathrm{~min}$ & $0.2 \%, 8 \mathrm{~min}$ & $\mathrm{H} 4$ & 0.0 & 4.4 & 0.36 \\
\hline & & & & H5 & 0.0 & 2.2 & 0.0 \\
\hline & & & & H6 & 0.0 & 1.3 & 0.0 \\
\hline & & & & $\mathrm{H} 7$ & 1.0 & 2.2 & 0.0 \\
\hline & & & & $\mathrm{H} 8$ & 1.0 & 0.0 & 0.0 \\
\hline & & & & H9 & 1.5 & 0.0 & 0.0 \\
\hline
\end{tabular}

Rooted shoots with leaf were transplanted on three substrates: black soil, black soil and sand $(1: 1)$ and sand. The seedling were placed in the culture room at $25 \pm 2{ }^{\circ} \mathrm{C}$ with $100 \%$ relative humidity under a photoperiod of 16 hours of light and continuously watered with tap water. After 4 weeks in the growing room, the seedlings were transferred outdoor where they were permanently watered. After 8 weeks under natural conditions, parameters such as viability rate, number of leaves per seedling and seedling size were recorded.

The collected data were subjected to an analysis of variance (ANOVA) using SPSS 20 software. Comparison of means was made using Duncan's test at the $5 \%$ probability threshold.

\section{Results and Discussion}

Disinfection is an obligatory step during in vitro culture since it aims to eliminate microbial contaminants that appear in the culture medium. In this work, the best embryo disinfection and explant reaction success rates (60 $\pm 10 \%$ and $80 \pm 4 \%$, respectively) were obtained in the presence of a few drops of alcohol and Triton X-100. They correspond to 
D2 and D3, in contrast to the low embryo disinfection rates $(0 \%)$ obtained with disinfectant solutions containing $30 \% \mathrm{NaClO}$ as the only chemical element (Table 2). The highest rate of disinfection ( $80 \%)$ resulted in the highest reaction rate $(80 \%)$. This can be explained by the presence of Triton X-100 which is a wetting agent. Indeed, Triton X-100 creates a permeability at the level of the pectocellulosic membrane allowing better penetration of the sodium hypochlorite in the explant. This result corroborates with those of Bürün and Çoban (2002) who during the disinfection of zygotic embryos from Hordeum Vulgare with ethanol and sodium hypochlorite supplemented with Tween- 80 (wetting agent), obtained a disinfection rate of $82.3 \%$. Tabi et al. (2016) also demonstrated the efficacy of wetting agents in disinfecting mature zygotic embryos of Elaeis guineensis.

Table 2. Effect of different chemical agents on the disinfection of mature seed embryos of Picralima nitida. D1: $10 \mathrm{~min}$ in sodium hypochlorite (NaClO) 30\%, D2: $30 \mathrm{~s}$ in ethanol 95 + $10 \mathrm{~min}$ in $\mathrm{NaClO} 30 \%$, D3: $8 \mathrm{~min}$ in 0.2\% Triton X-100 + $10 \mathrm{~min}$ in $\mathrm{NaClO} 30 \%, \mathrm{D} 4: 8 \mathrm{~min}$ in $0.2 \%$ Triton $\mathrm{X}-100+10 \mathrm{~min}$ in $\mathrm{NaClO} 40 \%$. Averages with the same letter in the same column are not significantly different at the $5 \%$ threshold.

\begin{tabular}{lccccc}
\hline $\begin{array}{l}\text { Disinfection } \\
\text { treatments }\end{array}$ & $\begin{array}{c}\text { Number of } \\
\text { Explants } \\
\text { sown }\end{array}$ & $\begin{array}{c}\text { Number of } \\
\text { Unpolluted } \\
\text { explants }\end{array}$ & $\begin{array}{c}\text { Rate of success } \\
\text { of disinfection } \\
(\%)\end{array}$ & $\begin{array}{c}\text { Number of } \\
\text { reacting } \\
\text { Explants }\end{array}$ & $\begin{array}{c}\text { Explant } \\
\text { Reaction } \\
\text { Rate (\%) }\end{array}$ \\
\hline D1 & 50 & $0^{\mathrm{a}}$ & $0 \pm 0^{\mathrm{a}}$ & $0 \pm 0^{\mathrm{a}}$ & $0 \pm 0^{\mathrm{a}}$ \\
D2 & 50 & $30^{\mathrm{b}}$ & $60 \pm 10^{\mathrm{b}}$ & $30 \pm 5^{\mathrm{b}}$ & $60 \pm 10^{\mathrm{b}}$ \\
D3 & 50 & $40^{\mathrm{c}}$ & $80 \pm 4^{\mathrm{c}}$ & $40 \pm 2^{\mathrm{c}}$ & $80 \pm 4^{\mathrm{c}}$ \\
D4 & 50 & $0^{\mathrm{a}}$ & $0 \pm 0^{\mathrm{a}}$ & $0 \pm 0^{\mathrm{a}}$ & $0 \pm 0^{\mathrm{a}}$ \\
\hline
\end{tabular}

The best germination rate $(100 \%)$ was obtained with the control medium (Fig. 1). The media $\mathrm{H} 5$ and $\mathrm{H} 2$ gave germination rates of $60 \%$ and $50 \%$ respectively. Mature zygotic embryos did not germinate on media H4, H6, H8 and H9. These results are contrary to those observed by Gbadamosi (2013), who in the absence of phytohormones, obtained the lowest germination rate of mature zygotic embryos of $P$. nitida $(40 \%)$. This difference could be due to the environment and cultural conditions which were not the same. The results obtained are similar to those of Devi et al. (2017) who, using the control medium, obtained germination rate $(73 \%)$ during the in vitro culture of mature zygotic embryos of Prunus persica.

After one month of culture, the rooting percentage was noted. It appears that the medium without phytohormones is the most favourable for rooting with $100 \%$ rooted explants demonstrating that the rooting of $P$. nitida embryos does not require an additional supply of phytohormones (Table 3). These results are similar with the development of Caesalpinia ferrea zygotic embryos (Da Silva et al. 2018), where the control medium had the highest rooting rate. They also found that exogenous phytohormones 
generally lead to the absence of root formation of the seeded explants. Souza and Pereira (2007) reported that in some species, particularly woody species, cultivated explants have difficulty in rooting in the presence of exogenous auxins. On the other hand, Jardim et al. (2010) explained that auxins added in the nutrient medium generally favour the stimulation of the root system. Cytokinins favour the formation of adventitious roots. Daffalla et al. (2011) during the culture of mature zygotic embryos of Boscia senegalensis showed that media without phytohormones had the same results $(67 \%)$ as those containing low quantities of auxins ( $0.25 \mathrm{mg} / \mathrm{IBA})$.

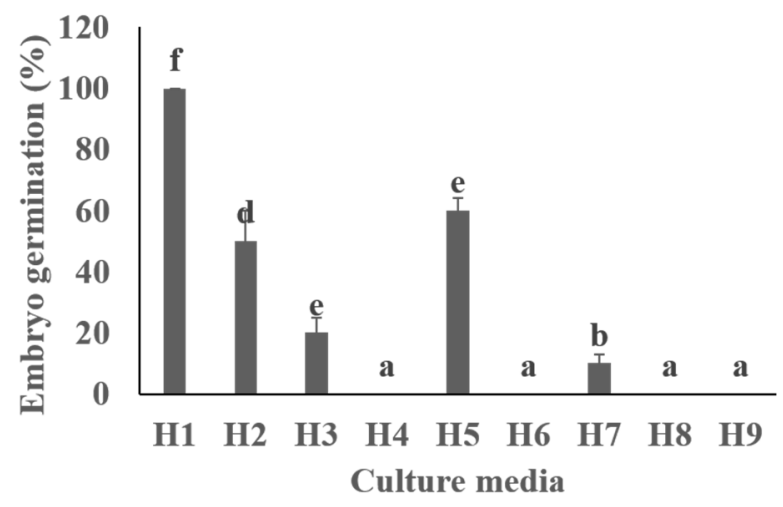

Fig. 1: Influence of media on the germination of mature zygotic embryos of P. nitida. H1 (control), H2 (2,4-D 1.8 $\mu \mathrm{M}), \mathrm{H} 3(\mathrm{BAP} 0.8 \mu \mathrm{M}), \mathrm{H} 4$ (BAP $4.4 \mu \mathrm{M}, 2,4-\mathrm{D} 0.36 \mu \mathrm{M}$ ); H5 (BAP $2.2 \mu \mathrm{M}$ ), H6 (BAP $1.3 \mu \mathrm{M})$, H7 (ANA 1 $\mu \mathrm{M}$, BAP $2.2 \mu \mathrm{M}$ ), H8 (ANA $1 \mu \mathrm{M}$ ), H9 (ANA $1.5 \mu \mathrm{M}$ ). The bars with the same letters are not significantly different at the $5 \%$ threshold.

Table 3. Effect of culture media on rooting parameters. H1: control, H2: 2,4-D at $1.8 \mu \mathrm{M}, \mathrm{H3}$ : BAP at $0.8 \mu \mathrm{M}, \mathrm{H} 4:$ BAP at $4.4 \mu \mathrm{M}+2,4-\mathrm{D}$ at $0.36 \mu \mathrm{M}$; H5: BAP at $2.2 \mu \mathrm{M}, \mathrm{H6}$ : BAP at 1.3 $\mu \mathrm{M}, \mathrm{H7}$ : ANA at $1 \mu \mathrm{M}+$ BAP at $2.2 \mu \mathrm{M}, \mathrm{H8}$ : ANA at $1 \mu \mathrm{M}, \mathrm{H9}$ : ANA at $1.5 \mu \mathrm{M}$. Averages with the same letter in the same column are not significantly different at the $5 \%$ threshold.

\begin{tabular}{lccc}
\hline Culture media & Rooting rate (\%) & $\begin{array}{c}\text { Number of roots per } \\
\text { embryo }\end{array}$ & $\begin{array}{c}\text { Average root lengths } \\
(\mathrm{cm})\end{array}$ \\
\hline H1 & $100 \pm 0^{\mathrm{d}}$ & $2 \pm 1^{\mathrm{b}}$ & $1 \pm 0,5^{\mathrm{bc}}$ \\
H2 & $11 \pm 4^{\mathrm{b}}$ & $1 \pm 1^{\mathrm{ab}}$ & $1,5 \pm 0,5^{\mathrm{c}}$ \\
H3 & $20 \pm 3^{\mathrm{c}}$ & $2 \pm 1^{\mathrm{b}}$ & $0,5 \pm 0,5^{\mathrm{ab}}$ \\
H4 & $0 \pm 0^{\mathrm{a}}$ & $0 \pm 0^{\mathrm{a}}$ & $0 \pm 0^{\mathrm{a}}$ \\
H5 & $10 \pm 2^{\mathrm{b}}$ & $1 \pm 1^{\mathrm{ab}}$ & $1 \pm 1^{\mathrm{bc}}$ \\
H6 & $0 \pm 0^{\mathrm{a}}$ & $0 \pm 0^{\mathrm{a}}$ & $0 \pm 0^{\mathrm{a}}$ \\
H7 & $10 \pm 4^{\mathrm{b}}$ & $1 \pm 0^{\mathrm{ab}}$ & $1,5 \pm 0^{\mathrm{c}}$ \\
H8 & $0 \pm 0^{\mathrm{a}}$ & $0 \pm 0^{\mathrm{a}}$ & $0 \pm 0^{\mathrm{a}}$ \\
H9 & $0 \pm 0^{\mathrm{a}}$ & $0 \pm 0^{\mathrm{a}}$ & $0 \pm 0^{\mathrm{a}}$ \\
\hline
\end{tabular}


For the average number of roots per embryo, it can be seen that the ability of roots to appear is not conditioned by the presence of phytohormones in the nutrient solution (Table 3). The results revealed that the control culture medium (H1) and the culture medium H3 (BAP at $0.8 \mu \mathrm{M})$ showed significantly $(\mathrm{P}<0.05)$ higher number of roots per embryo $(2 \pm 1)$ as compared to the culture media $\mathrm{H} 4$ (containing $4.4 \mu \mathrm{M}$ of BAP and 0.36 $\mu \mathrm{M}$ of 2,4-D), H6 (BAP at $1.3 \mu \mathrm{M}$ ), H8 (NAA at $1 \mu \mathrm{M}$ ) and H9 (NAA at $1.5 \mu \mathrm{M}$ ) in which there was no root formation. These results are contrary to those of Daffalla et al. (2011) who obtained the highest root counts per embryo with the control $(1.0 \pm 0.3)$ and MS media supplemented with IBA at $0.25 \mathrm{mg} /(1.2 \pm 0.4)$.

Root elongation is a very sensitive stage in the concentration of auxins. In this work, the combination of different phytohormones significantly $(\mathrm{P}<0.05)$ influences roots elongation during in vitro culture of mature zygotic embryos of Picralima nitida (Table 3). The best results $(1.5 \mathrm{~cm})$ were obtained using 2,4-D at $1.8 \mu \mathrm{M}, \mathrm{NAA}$ and BAP at $1 \mu \mathrm{M}$ and $2.2 \mu \mathrm{M}$ respectively (Fig. 2f). The results showed that 2,4-D at a concentration of 1.8 $\mu \mathrm{M}$ is required for root elongation. These results are contrary to those of Baker and Wetzstein (1994) who obtained good results using BAP at $4.4 \mu \mathrm{M}$. This difference could be explained by the type of phytohormones used. Tiaz and Zeiber (2002) found that root elongation requires low concentrations of auxin. At high values, auxin induces ethylene production and inhibits rooting. Baker and Wetzstein (1994) reported that high auxin concentration induces the degradation of secondary metabolites in explant tissues thus blocking the regeneration process.

Table 4. Effect of substrate on seedling development. Averages with the same letter in the same column are not significantly different at the $5 \%$ threshold.

\begin{tabular}{lccc}
\hline Substrate & $\begin{array}{c}\text { Success rate } \\
(\%)\end{array}$ & $\begin{array}{c}\text { Number of leaves } \\
\text { per seedling }\end{array}$ & $\begin{array}{c}\text { Seedlings pruning } \\
(\mathrm{cm})\end{array}$ \\
\hline Black soil & $30 \pm 2^{\mathrm{b}}$ & $4 \pm 2^{\mathrm{b}}$ & $2 \pm 1^{\mathrm{b}}$ \\
Black soil/sand (1:1) & $30 \pm 3^{\mathrm{b}}$ & $2 \pm 1^{\mathrm{ab}}$ & $1 \pm 0^{\mathrm{ab}}$ \\
Sand & $0 \pm 0^{\mathrm{a}}$ & $0 \pm 0^{\mathrm{a}}$ & $0 \pm 0^{\mathrm{a}}$ \\
\hline
\end{tabular}

After 30 days of cultivation, the explants with long roots and leaf outlines were transferred to the pots containing the various substrates (black soil, black soil/sand and sand) for acclimatisation (Fig. 2g). Substrate significantly $(\mathrm{P}<0.05)$ influences the development of the seedling (Table 4). The black soil and black soil/sand showed the same results for the success rate $(30 \pm 2 \%)$, for the number of leaves per seedling $(4 \pm 2)$ and the size of the seedlings $(2 \pm 1 \mathrm{~cm})$. This could be explained by the fact that the species under natural conditions thrive on the soil as on the substrate made of black soil and sand. These same substrates have been used by Pant and Joshi (2008) successfully for the acclimatisation of Rauvolfia serpentina in vitro seedlings. 
The results obtained varied according to the nature of the substrate; after root elongation, recovery in controlled and confined conditions was observed only on black earth and black earth + sand substrates. One week after their transfer in natural condition, only 65 and $60 \%$ of the in vitro seedlings present in these two substrates could regenerate the plantlets (Fig. 2g). The seedlings from the MZE culture resumed their growth without difficulty because of their pivoting root system.
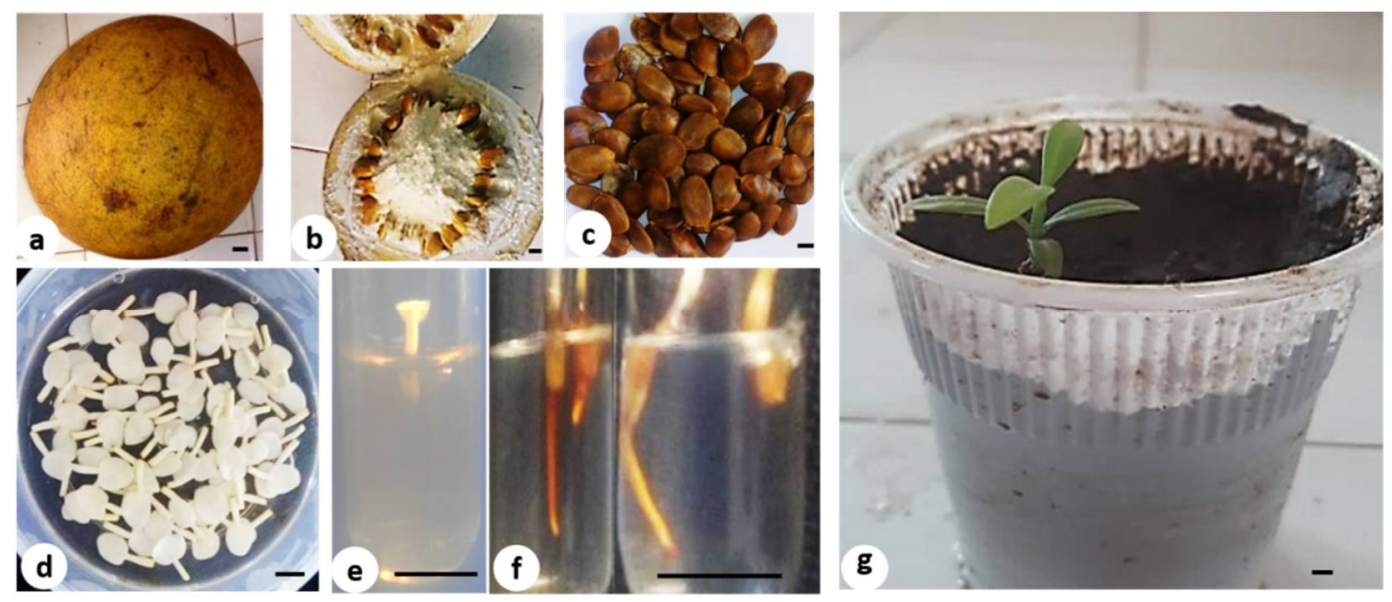

Fig. 2a-g: From mature fruit to plantlet through in vitro developmental stages of mature zygotic embryo culture of Picralima nitida. a. entire ripen fruit. b. cross section of the fruit. c. entire seeds. d. extracted embryos. e. embryo explant on culture medium. f. rooted in vitro explants. g. 60 days old acclimatised plantlet of $P$. nitida. scale bars represent $1 \mathrm{~cm}$.

In conclusion, the physiological conditions favourable for disinfection and in vitro germination and regeneration of Picralima nitida from mature zygotic embryos was established. The disinfection method consisting of $95^{\circ}$ ethanol for $30 \mathrm{~s}$ and $30 \%$ sodium hypochlorite for $10 \mathrm{~min}$ as well as $0.2 \%$ of Triton X-100 for $8 \mathrm{~min}$ and $30 \%$ sodium hypochlorite for $10 \mathrm{~min}$ provided the highest disinfection success rate. The best rates of germination and rooting of the embryos were obtained without the addition of phytohormones to the culture medium. On the other hand, NAA $(1 \mu \mathrm{M}), \mathrm{BAP}(0.8$ to 2.2 $\mu \mathrm{M})$, and 2,4-D $(1.8 \mu \mathrm{M})$ is essential to induce root formation and root elongation. Concerning acclimatisation, it appears that black soil and black soil/sand are favourable substrates for the development of seedlings.

\section{References}

Baker CM and Wetzstein HY (1994) Influence of auxin type and concentration on peanut somatic embryogenesis. Plant Cell Tissue Organ Cult. 36(3): 361-368.

Bürün B and Çoban PE (2002) Embryo culture in Barley (Hordeum vulgare L.). Turk. J. Biol. 26: 175-180. 
Chin HF, Krishnapillay B and Stanwood PC (1989) Seed moisture: recalcitrant vs orthodox seeds. In Stanwood PC and Mc Donald MB eds. Seed Moisture. CSSA/Crop Science Society of America, Madison: 15-22.

Da Silva D, Imakawa AM, de Souza Costa S and Sampaio PTB (2018) In vitro culture of zygotic embryos and seeds of Caesalpinia ferrea Martius. Hoehnea 45(4): 663-668.

Daffalla HH, Abdellatef E and Khalafalla MM (2011) Effect of growth regulators on in vitro morphogenic response of Boscia senegalensis (Pers.) Lam. Poir. using mature zygotic embryos explants. Biotechnol. Res. Int.1-8.

Devi I, Singh H and Thakur A (2017) Effect of developmental stage and medium on embryo culture of low chill peach hybrids. Curr. Sci. 113(9): 1771-1775.

Fakeye A, Itiola OA, George AO and Odelola HA (2004) Antimicrobial property of Picralima nitida stem bark extract in cream formulations. Pharm. Biotechnol. 42(45): 274-279.

Fuentes G, Talavera C, Oropeza C, Desjardins Y and Santamaria JM (2005) Exogenous sucrose can decrease in vitro photosynthesis but improve field survival and growth of coconut (Cocos nucifera L.) in vitro plantlets. In Vitro Cell. Dev. Biol. Plant 41: 69- 76.

Gautheret R (1959) Sur la potentialité de réaliser la culture indéfinie des tissues tubercules de carotte. C.R. Soc. Biol. Paris 208: 118-120.

Gbadamosi AE (2013) In-vitro propagation of Picralima nitida (Stapf) through embryo culture. Afr. J. Biotechnol. 12(22): 3447-3454.

Grosser JW and Gmitter JFG (2011) Protoplast fusion for production of tetraploids and triploids: application for scions and rootstock breeding in Citrus. Plant Cell Tissue Org. Cult. 104: 343-357.

Inkoto CL, Kayembe, JPK, Mpiana PT and Mgbolua K-te-N (2020) A review on the phytochemistry and pharmacological properties of Picralima nitida Durand and $\mathrm{H}$. (Apocynacea family): A potential antiCovid-19 medicinal plant species. Emer Life Sci Res. 6(1): 64-75

Inya-Agha SI, Ezea SC and Odukoya OA (2006) Evaluation of Picralima nitida hypoglycemic activity, Toxocity and Analytical Standards. Int. J. Pharmacol. 2(5): 576-580.

Jardim LS, Sampaio PTB, Costa SS, Gonçalves CQB, and Brandão HLM (2010) Efeito de diferentes reguladores de crescimento na regeneração in vitro de pau-rosa (Aniba rosaeodora Ducke). Acta Amazonica 40(2): 275-280.

Jiofack T, Ayissi I, Fokunang C, Guedje N and Kemeuze V (2009) Ethnobotany and phytomedicine of the upper Nyong valley forest in Cameroon. Afr. J. Pharm. Pharmacol. 3(4): 144-150

Jiofack T, Fokumang C, Guedje N, Kemeuze V, Fongnzossie E, Nkongmeneck BA, Mapongmetsem PM and Tsabang N (2010) Ethnobotanical uses of medicinals plants of two ethnoecological regions of Cameroun. Int. Med. Med. Sci. 60-79.

Kouitcheu MLB, Penlap BV, Kouam J, Ngadjui BT, Fomum ZT and Etoa FX (2006) Evaluation of antidiarrhoeal activity of the fruit-rind of Picralima nitida (Apocynaceae). Afr. J. Trad. CAM 3(4): 66-73.

Ledo AS, Gomes KKP, Barboza SBSC, Vieira GSS, Tupinambá EA, Aragão WM (2007) Cultivo in vitro de embriões zigóticos e aclimatação de plântulas de coqueiroanão. Pesquisa Agropecuária Brasileira 42: 147-154. 
Ledo AS, Lameira OA, Benbadis AK, Menezes IC, Ledo CAS, Oliveira MSP (2001) Cultura in vitro de embriões zigóticos de açaizeiro. Revista Brasileira de Fruticultura 23: 468-472.

Nkere CK and Iroegbu CU (2005) Antimicrobial property of Picralima nitida stem and roots bark extract. Afr. J. Biotechnol., 4(6): 522-526

Nwakile CD and Okere VC (2011) Picralima Nitida seed oil: Hypoglycemic activity. Adv. J. Pharm. Educ. Res. 2: 147-150.

Ogbole OO, Akinleye TE, Segun PA, Faleye TC and Adeniji AJ (2018) In vitro antiviral activity of twenty seven medicinal plant extracts from Southwest Nigeria against three serotypes of echoviruses. Virol. J. 15(1): 110

Okunji CO, Iwu MM, Ito Y and Smith PL (2005) Preparative separation of indole alkaloids from the rind of Picralima nitida (Stapf) T. Durand and H. Durand by $\mathrm{pH}$ zone-refining counter current chromatography. Liq. J. Chrom. Rel. Tech. 28(5): 775-783.

Pant KK and Joshi SD (2008) Rapid multipliation of Rauvolfia serpentina Benth. ex kurz through tissue culture. Sci. World 6(6): 58-61

Souza AV, Pereita AMS (2007) Enraizamento de plantas cultivadas in-vitro. Rev. Bras. Pl. Med. Botucatu 9: 103-117.

Tabi MK, Tonfack LB, Ntsomboh NG, Bilal AM, Ngando EGF, Ngaha D, Njembele C, Kato SN and Youmbi E (2016) Mature zygotic embryo rescue improves in vitro germination and seedling production in high value oil palm (Elaeis guineensis Jacq). Ind. Crops Prod. 94: 445-453

Taiz L and Zeiger E (2002) Mineral nutrition: Plant Physiology. Sinaver Associates, 2nd edition, Sunderland, pp. 67-86.

Thawaro S and Te-Chato S (2010) Effect of culture medium and genotype on germination of hybrid oil palm zygotic embryos. Sci. Asia 36: 26-32.

Tzec-Simá MA, Orellana R and Robert ML (2006) In vitro rescue of isolated embryos of Bactris major Jacq. and Desmoncus orthacanthos Mart., potentially useful native palms from the Yucatan Peninsula (Mexico). In Vitro Cell. Develop. Biol. Plant 42: 54-58.

(Manuscript received on 21 October, 2021; revised on 9 December, 2021) 